\title{
EMBRYONIC DEVELOPMENTAL STAGES OF IKAN PALMAS (Polipterus senegalus senegalus)
}

\author{
I Wayan Subamia*), Media Fitri Isma Nugraha*), and Slamet Sugito*)
}

\begin{abstract}
The purpose of these observations was to identify the stages of the embryo development of ikan palmas (Polypterus senegalus senegalus) and determine the length of duration of each stage. Broodstocks were cultured in aquaria $6 \times 72 \times 50 \mathrm{~cm}$ in size. The broodstock were stocked at ratio of $1: 1$ and fed ad libitum with earthworm, small feed fish (ting sea fish) and golden snail. The Palmas broodstocks here naturally spawned in artificial nests made of split plastic raffia in resembling the aquatic plant found in the natural habitat of ikan palmas. After 21 days of culture period, the broodstock began to lay eggs in gradually for 20 days. The average diameter of the eggs was $25 \mu \mathrm{m}$. The embryo developed in 24 hours after fertilization and hatched out three days after the embryo had developed.
\end{abstract}

\section{KEYWORDS: embryo development, Polypterus senegalus senegalus, stage of development}

\section{INTRODUCTION}

One of the ornamental fish species which have high economic value is Polypterus senegalus senegalus or its common name is "Senegal bichir" popularly known in Indonesia as ikan palmas. It originated from Africa and western Tanzania (Komagata et al., 1993) where the adult size can reach a total length of $40 \mathrm{~cm}$ (about 16 inches). The fish live in tropical waters with temperature of $25-28^{\circ} \mathrm{C}$ and $\mathrm{pH}$ from neutral to acid. They are very tolerant to live in poor water quality. Polypterus spp are also known as "a living fossil, providing evidence for the origin of paired limbs from fish, fin and consequently as a missing link between fishes and amphibians" (Hall, 2001). It consists of 18 spesies (Anynomous, 2008), which are considered rare species hence the need for culturing them in order to conserve their population. The Research Institute for Freshwater Ornamental Fish Culture at Depok has been successful in domestication of five of the species of Polypterus namely Polypterus senegalus senegalus, Polypterus albino,
Polypterus ornatipinnis, Polypterus endlicheri endlicheri, and Polypterus ornatipinnis.

Understanding the development of embryo is very important considering that each species has its own time duration of the developmental stage which is different from the time of developmental stage of the embryo of other species. The embryonic development of palmas is considered very important as Hall (2001) said, "the goal of two turn-of-thecentury biologists-Jhon Samuel Budgett and Nathan Russel Harington, both of whom died in the attempt - was to document the embryonic development of Polypterus, a fish found in lakes, river margins, swamps and flood plains in tropical region of central and western Africa and the Nile river system. Jhon Samuel Budget, the more successful of the two, undertook four long and arduous expeditions between 1898 and 1903. The embryos that he collected provided the basis for our understanding of Polypterus development for almost 100 years. This is the story of the pursuit of Polypterus and its importance in finding missing links

\footnotetext{
"Research Institute for Freshwater Ornamental Fish Culture Depok, Indonesia
} 
between fishes and tetrapods. The embryonic development of this fish species is still a mystery as Hall (2001) said, "no documented records are available on the embryonic development of Polypterus"

In addition, knowledge on the stages of embryonic development is required as basis to look for the patterns of embryonic development under natural conditions (Suwirya \& Andamari, 2008). According to Abercrombie et al. (1990), the embryo is a structure developed by the fertilized egg and undergoes the process of mitosis when it is still within the egg membrane or within the maternal body. Usually, the life of embryo is completely understood at the time of hatching (birth). Fried \& Hademenos (2002) said that in all higher organisms, embryonic processess include: (1) cell division or growth, (2) specialization of cells into tissues which are very differentiated, (3) formation of an adult organism with a unique form and a system of functional organs.

The objectives of the observations were to identify the stages of embryonic development of ikan palmas (Polypterus senegaus senegalus) and to determine the period of time needed for each stage of embryonic development.

\section{MATERIALS AND METHODS}

In July $31^{\text {rst }}$, 2008, Palmas (Polypterus senegalus senegalus) was spawned successfully in a natural way, laid eggs gradually and continually for 20 days with an average of 200 eggs daily. The spawning process took place in an artificial nests made of plastic raffia to resemble its nest in the natural habitat (Figure 1). Spawning was conducted in the natural way by pairing one female with one male broodstock in an aquarium $60 \times 70 \times 50 \mathrm{~cm}$ in size. In the aquarium, two artificial nests made of split plastic raffia were placed and arranged to bear a resemblance of the aquatic plant (pakis), similar to the fish natural habitat in which male and female broodstocks will breed. During the maturation process of eggs and sperms, palmas broodstocks were fed with earthworm, small fish (teri) and golden snail. After three weeks, the broadstocks spawned. Spawning took place around 11.00-12.00 midnights, as well as in day time at around $11.00 \mathrm{am}-12.00$ noon. The laid eggs were collected, in the next morning around 7.30 am local time (WIB), whereas the eggs produced in day time were collected around $2.00 \mathrm{pm}$ (WIB). Egg collections were conducted by following suitable time interval in order to avoid disturbing the process of eggs or sperm emission by the broodstock during that time. The emitted fertilized eggs were then taken out by siphoning with a plastic tube of one $\mathrm{cm}$ in diameter. These eggs were then transferred into another aquarium that had been filled with water $18 \mathrm{~cm}$ depth, supplied with moderate aeration and treated with addition of some Methylane Blue to prevent possible fungal growth. The aquarium water temperature was raised by using a heater, to $28-29^{\circ} \mathrm{C}$. If the eggs were not taken out within two hours, the male broodstocks will probably eat them. The embryos were observed by first taking out the fertilized eggs immediately after fertilization or emission of eggs and sperm produced by the pair of broodstocks and then examined the fertilized eggs under the microscope SZX 9 at a magnification of 10x. The parameters observed were the interval time needed to proceed from one stage of development to the next stage.
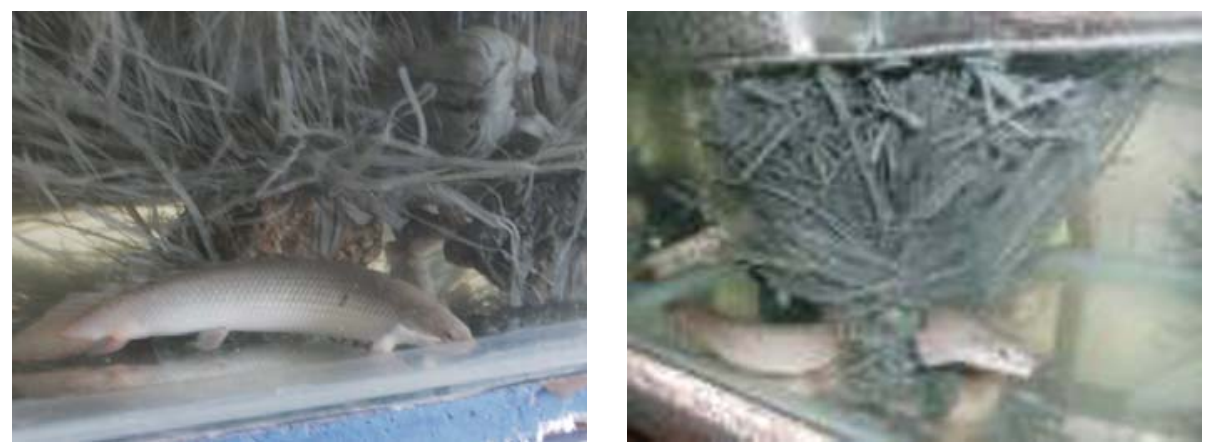

Figure 1. The Polypterus senegalus senegalus broadstock and the artificial nest in which the broadstock will lay its egg 


\section{RESULTS AND DISCUSSIONS}

The eggs of palmas are rounded, white and black in colours. These colours can serve as indicators whether the egg has been fertilized or not. The fertilized egg has two colours and two sides, black and white sides separated by an equator-like boundary line (Figure 2). Fertilized egg can easily be distinguished from those not fertilized where fertilized egg always has the upper black side covering the white side, whereas the egg that was not fertilized has no black side, or it has white side only. The eggs sticked to the bottom of aquarium. The first embryo cell division developed within 24 hours. After completions of the cell divisions, the tail and head began to form. The egg diameter became shorter and sharp. The time period needed for each configuration and development of the embryo are presented in Table 1.

The carapace that covered the embryo was elliptical $38 \mu \mathrm{m}$ in width and $45 \mu \mathrm{m}$ in length, while the embryo of palmas was $45 \mu \mathrm{m}$ in length. The volume of carapace was progressively shrinking with the increasing size of the embryo. In the hatching process, the first

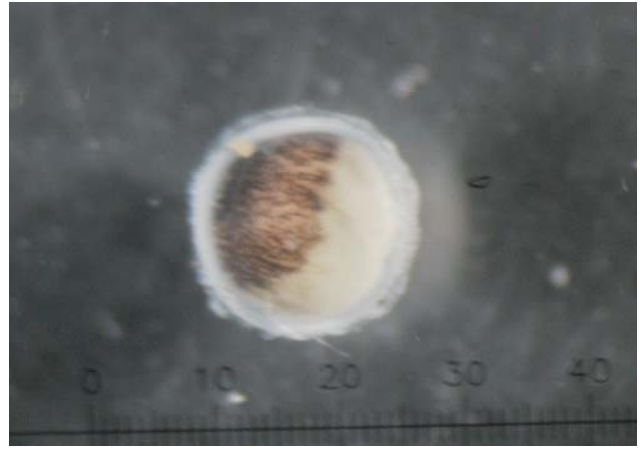

Figure 2. Singular cell. The egg of Polypterus senegalus senegalus has 2 poles (black and white pole) bordered by an equatorial area

part of larva body that sticked out was the head then the body and finally the tail.

Result of observation on the embryonic development stages and the period of time needed by cell stage are indicated in Table 1 .

Figures 3-7 are embryogenesis process of Polypterus senegalus senegalus.

Table 1. Embryonic developmental stages of Palmas (Polypterus senegalus-senegalus)

\begin{tabular}{clc}
$\begin{array}{c}\text { Stage } \\
\text { Number }\end{array}$ & Stage Descriptions & $\begin{array}{c}\text { Time Spent during the Stage Measured } \\
\text { from the Beginning of Fert ilization } \\
\text { (hours) }\end{array}$ \\
\hline 1 & One cell & $00: 00: 00$ \\
2 & 2 cells & $00: 35: 00$ \\
3 & 4 cells & $00: 90: 00$ \\
4 & 8 cells & $01: 02: 00$ \\
5 & 16 cells & $01: 63: 00$ \\
6 & Many cells & $02: 00: 00$ \\
7 & Beginning of blastula & $02: 60: 00$ \\
8 & End of blastula & $03: 11: 00$ \\
9 & Beginning of grastula & $04: 55: 00$ \\
10 & End of grastula & $04: 75: 00$ \\
11 & Beginning of differentiation & $04: 84: 00$ \\
12 & End of differentiation & $16: 50: 00$ \\
13 & Embryo developed & $17: 35: 00$ \\
14 & Eyes formed & $18: 00: 00$ \\
15 & Haching & $114: 00: 00$ \\
16 & Lanva began to be fed & $288: 00: 00$
\end{tabular}




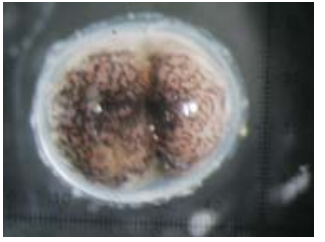

(a)

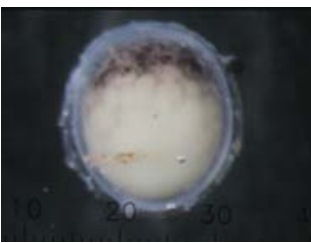

(e)

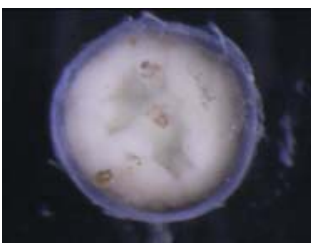

(i)

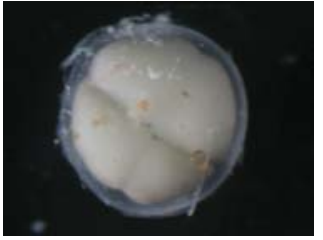

(b)

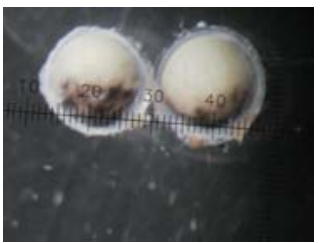

(f)

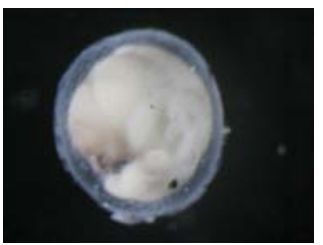

(j)

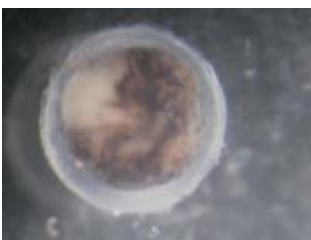

(m)

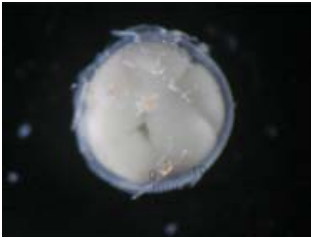

(c)

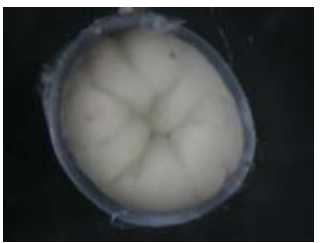

(g)

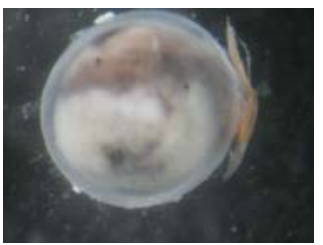

(k)

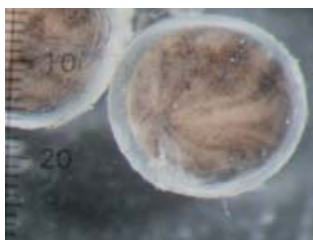

(n)

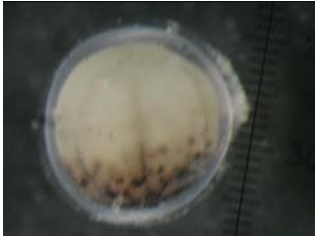

(d)

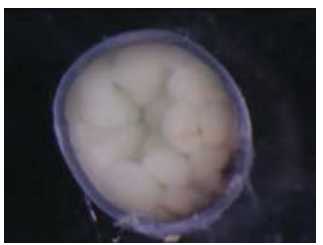

(h)

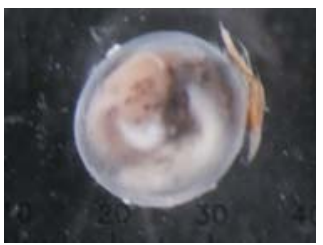

(l)

Description: a) Division process of a cell into two cells, b) Division process of two cell into four cells, c) Division process of four cell into egiht cells, d) Division process of cell viewed from the side, e) Many cells, f) Morula stage, g) Blastula cavity formation begins (initial blastula), h) Blastula begins, i) Initial gastrula, j) Final gastrula, k) Cell differentiation begins, I) Cell differentiation near completion indicated by the appearance of the black pole covering the white pole, $m$ ) the white pole has shrunk, $n$ ) Differentiation completed, the white pole has been covered, embryo begins

Figure 3. Stages of cell division and cell differentiation

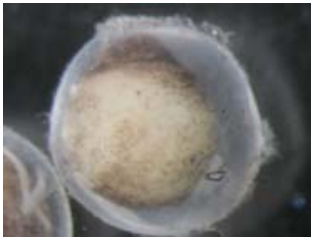

(a)

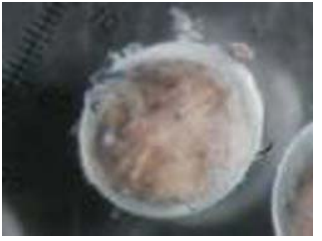

(b)

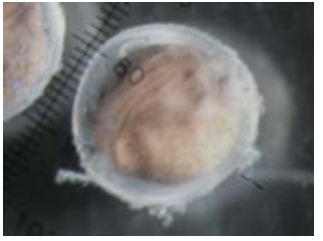

(c)

Description: a) egg yolk formation, b) Initial embryo, c) Eyes formed

Figure 4. Process of embryo formation 


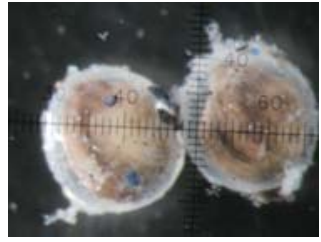

(a)

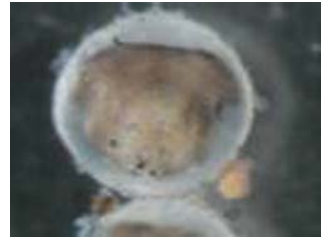

(b)

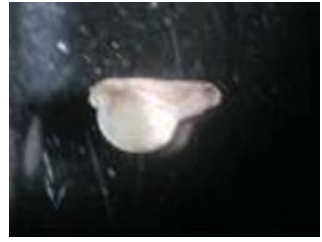

(c)

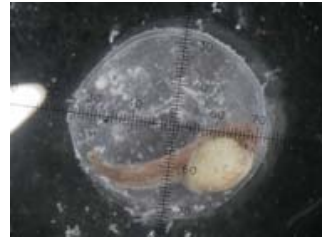

(d)

Description: a) and b) initial embryo, c) Developing embryo, d) Embryo about to hatch out

Figure 5. Development of embryo

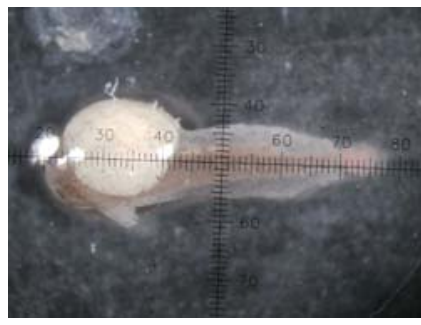

(a)

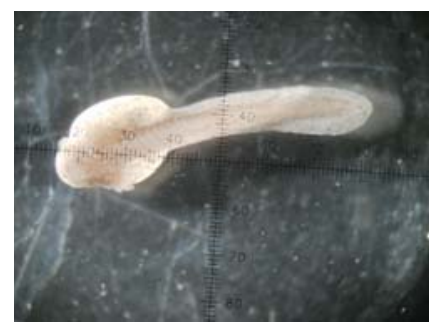

(b)

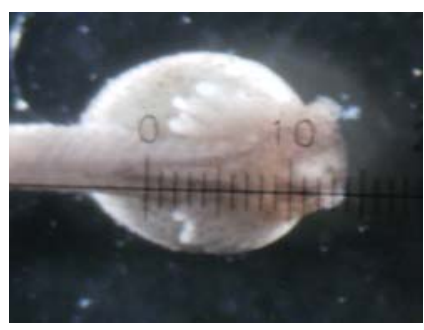

(c)

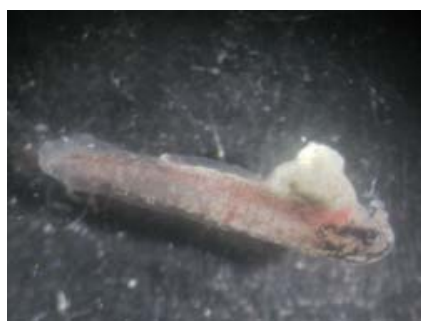

(a)

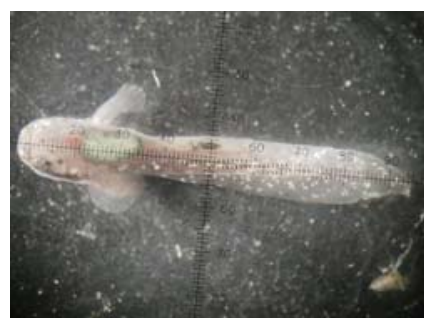

(b)

Description: a) Egg hatched out, b) Tail coat beginning to disappear, c) Gill fins have formed 3 days after hatching, d) Egg yolk gradually depleted 5 days after hatching, e) Egg yolk begins fully depleted 6 days after hatching

Figure 6. Egg hatched out 4 days after embryo has formed

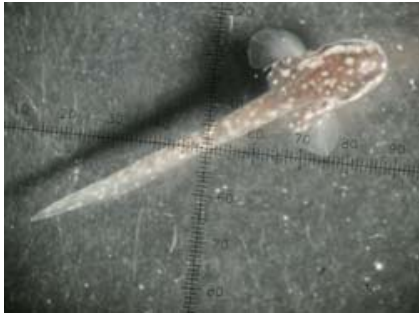

(a)

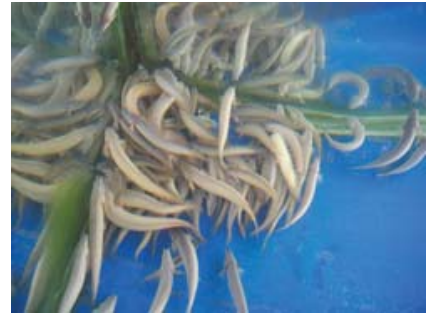

(b)

Description: a) 7 days old Larva, b) 80 days old larva

Figure 7. Development of larva 


\section{CONCLUSIONS}

Polypteus senegalus senegalus lays partially eggs every day for 3 weeks, with average of 200 laid eggs daily. The first cell division began 30 minutes after fertilization of the egg. The embryo formed 24 hours after the first cell division. The egg hatched out after 72 hours embryo formation. The embryonic eggs had two poles, black and white poles which were bordered by an equatorial-like line. The end of the black pole was the spot through which the larval head came out and the end of the white pole was the spot through which the larval tail came out. When the gastrula process completed, the black pole covering the white pole and the cell differentiation began to form embryo structure. The process of embryo formation after the first cell division took place 24 hours for completion. The gill fins then began to form on the third day after hatching.

\section{REFERENCES}

Abercrombie.M., M. Hickman, M.L. Johnson, and M. Thain. 1990. Kamus lengkap biologi. Penerbit Erlangga. Jakarta.

Anynomous. 2008. http://www.polypterus. info/keeping_polypterus.htm. Akses tanggal 09 September 2008.
Fried. G. and G.J. Hademenos. 2002. Schaum outlines of biologi. Edisi Kedua. Penerbit Erlangga. Jakarta.

Hall, B.K. 2001. John Samuel Budgett (18721904): In Pursuit of Polypterus. Published by: America institute of Biological Science. Bioscience. Mei 2001 . 51(5): 399-407.

Komagata. K., A. Suzuki and R.Kuwabara. 1993. Sexual dimorphism in the Polypterid Fishes, Polypterus senegalus and Calamoichthys calabaricus. Japanese Journal of Ichthyology. Vol. 39 No.4.

Suwirya, K. and R. Andamari. 2008. Perkembangan embrio lemak dan asam lemak pada larva kerapu sunu (Plectropomus Leopardus) pada stadia awal. Prosiding Seminar Nasional Tahun V Hasil Penelitian Perikanan dan Kelautan. Kerja Sama Jurusan Perikanan dan Kelautan Fakultas Pertanian Universitas Gadjah Mada dengan Balai Besar Riset Pengolahan Produk dan Bioteknologi Kelautan dan Perikanan Badan Riset Kelautan dan Perikanan. 